\title{
Öyküsel Terapi: Felsefi ve Kuramsal Temelleri, Terapi Teknikleri ve Etkinliği
}

\author{
Narrative Therapy: Philosophical and Theoretical Foundations, Therapy \\ Techniques and Efficacy
}

\section{Koray AKKUŞ * Bahtım KÜTÜK Belemir Şule SAMAR ${ }^{* * *}$}

Öz: Öyküsel terapi 1980'li y1llardan itibaren gelişmeye başlayan ve özellikle ülkemizde görece daha az bilinen bir psikoterapi yaklaşımıdır. Bu yaklaşım hem dayandığı felsefi ve teorik ilkeler hem de kullandığı terapi yöntemleri açısından geleneksel psikoterapi yöntemlerinden oldukça farklılaşmaktadır. Postmodernist ve sosyal inşacı bir psikoterapi yaklaşımı olan öyküsel terapide temel odak danışanların sahip oldukları hikayelerdir. Öyküsel terapi, bireylerin ve ailelerin yaşadıkları sorunları danışan hikayeleri üzerinden anlamaya çalışmakla birlikte politik ve kültürel etmenlerin bu sorunlar üzerinde önemli bir etkisinin olduğunu öne sürer. Bu makalede, öncelikle öyküsel terapinin dayandığı felsefi temeller ve varsayımlar açıklanmış; terapistin konumu, kullanılan teknikler ve terapi süreci hakkında bilgi verilmiştir. Sonrasında ise öyküsel terapinin etkililiği üzerine yurtiçinde ve yurtdışında yapılan araştırmalar gözden geçirilmiştir. Bu derlemeye dahil edilen etkililik çalışmaları hakkında detaylı bilgiler verilmiş ve bulguları özetlenmiş̧ir. Alanyazın incelemesi sonucunda, öyküsel terapinin etkililiğini araştıran yüksek nitelikli çalışmaların sayısının hem ülkemizde hem de yurtdışında oldukça kısıtlı olduğu görülmüştür. Bununla birlikte, az sayıdaki bu çalışmaların bulguları, öyküsel terapinin çeşitli psikolojik sorunlara ilişkin belirtilerin azaltılmasında fayda sağlayabileceğine işaret etmektedir.

Anahtar sözcükler: Öyküsel Terapi, Aile Terapisi, Postmodernizm, Sosyal İnşacıllk, Etkinlik

Abstract: Narrative therapy has started to develop in the 1980s; and it is a relatively less known psychotherapy approach, especially for our country. It highly differs from traditional psychotherapy methods in terms of both the based philosophical, theoretical principles and used therapy methods. The main focus of the narrative therapy, which is a postmodernist and socially constructive psychotherapy approach, is the stories of the clients. Narrative therapy tries to understand the individual and family problems through client stories, and it suggests that political and cultural factors have a significant effect on those problems. In this article, philosophical foundations and assumptions on narrative therapy are primarily explained and then general information about the position of the therapist, used techniques, and therapy process is provided. Next, the studies conducted on the effectiveness of narrative therapy in Turkey and other countries were reviewed. The detailed information about effectiveness studies included in this review is given and their findings are summarized. Based on the reviewed literature, it is found that the number of high-quality studies on that topic is very limited in both Turkey and other countries. However, the findings of these few studies indicate that narrative therapy can benefit to reduce the symptoms of various psychological problems.

Keywords: Narrative therapy, Family Therapy, Postmodernism, Social Constructivism, Efficacy

\footnotetext{
Arş. Gör., Ege Üniversitesi, Psikoloji Bölümü, İzmir. koray_akkus@yahoo.com, https://orcid.org/0000-0002-3769-1306

** Arş. Gör., Ege Üniversitesi, Psikoloji Bölümü, İzmir. bahtimkutuk_ege@ hotmail.com, https://orcid.org/0000-0001-7190-6190

**** Arş .Gör., Ege Üniversitesi, Psikoloji Bölümü, İzmir. bsulesamar@hotmail.com, https://orcid.org/0000-0001-5406-4411
} 


\section{Giriş}

Danışanların terapiye getirdiği hikayeler üzerinden insan deneyimini anlamaya çalışan öyküsel terapi, postmodernist anlayışa dayanan ve geleneksel terapi yaklaşımlarından önemli ölçüde ayrılan bir terapi yöntemidir (Morgan 2000; Parry \& Doan 1994). Sistemik olmayan bu terapi yönteminde, bireylerin ve ailelerin ulaşması gereken evrensel prensiplerden söz edilmez ve danışanlarla yapılan çalışmalar bir özgürleşme süreci olarak görülür. Süreç odaklı ve sosyal inşacı bir yaklaşım olan öyküsel terapide, sorunların nedenlerinden ziyade anlamları ve bu sorunların istisnaları üzerinde çalışılır (Gladding 2012).

1980'li yılların sonunda aile terapisi alanında yaşanan dört önemli gelişme öyküsel terapinin gelişimine zemin hazırlamıştır (Polkinghorne 2004). Bunlardan ilki, terapideki odağın, danışanların sorunları veya zayıflıkları yerine, güçlü yanlarına ve sorun çözme kaynaklarına yöneltilmesidir. İkincisi, danışanların birer nesne olarak görülerek uzman terapistler tarafından gözlenmesi veya sınıflandırılması fikrinin yerine, danışan ile terapistin eşit seviyede ilişki kuran birer partner oldukları görüşünün yerleşmesidir. Üçüncü gelişme, dürtü, savunma mekanizmaları ve intrapsişik gerilimler gibi kavramların yerine aile üyelerinin olaylara yükledikleri anlamların önem kazanmasıdır. Son gelişme ise terapi sürecinde danışanların benlik öykülerinin (selfstories) terapinin merkezine alınmasıdır (Polkinghorne 2004). Son yıllarda ülkemizde çeşitli yayınlarda (örn. Çelik 2017; İlgar \& İlgar 2018) öyküsel terapi ele alınmakla birlikte, farklı psikolojik sorunlarda bu terapi yaklaşımının etkinliğine yönelik bilgilerin eksik olduğu görülmektedir. Bu eksikliği gidermek ve öyküsel terapi literatürüne katkıda bulunmak amacıyla, öncelikle bu yaklaşımın kuramsal temelleri ve terapi süreci açıklanmıştır. Daha sonra Scopus, Sciencediret, Google akademik veri tabanlarında ve Yöktez sisteminde "öyküsel terapi" ve "depresyon", "kaygı bozukluğu”, "obsesif kompülsif bozukluk", "travma sonrası stres bozukluğu", "etkililik" gibi anahtar kelimeler zaman kısıtlaması olmadan farklı kombinasyonlarla İngilizce ve Türkçe olarak taranmıştır. Öyküsel terapinin çeşitli psikolojik sorunlardaki etkililiğini araştıran deneysel ve yarı-deneysel çalışmalar derlemeye dahil edilirken; etkililik çalışması olmayan ve vaka çalışması türündeki araştırmalar dahil edilmemiştir.

\section{Postmodernizm ve Sosyal İnşacılık: Felsefi Temeller}

Postmodernist yaklaşım, bilgilerin ve doğruların keşfedilen değil, yaratılan süreçler olduğunu öne sürer. $\mathrm{Bu}$ temel kabulden etkilenen öyküsel terapi, psikoterapi alanına egemen olan pragmatik, görgül terapilere ve sağlık bakım sistemlerine bir alternatif bakış açısı sunar (Besley 2002). Geleneksel terapi yöntemlerinin dayandığı modernist yaklaşım, güvenebileceğimiz ve keşfedebileceğimiz evrensel doğrular olduğunu varsayarken, postmodernizm büyük politik, felsefi ve dini anlatıların dünyayı açıklamakta yetersiz kaldığını öne sürer. Böylelikle tek bir evren anlayışının yerine, çoklu evren anlayışı önem kazanır ve bireysel deneyimler ön plana çıkar (Karaırmak \& Bugay 2010). Öyküsel terapinin odaklandığı temel nokta anlamların nasıl genelleştirildiği ve bu anlamların gerçekliği nasıl inşa ettiğidir (Doan 1998). Bu bağlamda, insanların deneyimlerine yükledikleri özel anlamlar olarak tanımlanan öykü kavramı veya metaforu önem kazanmaktadır. İnsanların hayatlarına anlam vermek ve şekillendirmek için kullandıkları bu öyküler (Çelik 2017), zaman içerisinde deneyimlenen olayların bir araya getirilmesi ve açıklanmasıyla oluşturulur. İnsanlar aynı anda birçok farklı öykü içerisinde yaşarlar ve aynı olay için farklı öykü anlatabilirler (Morgan 2000). Postmodernist yaklaşımda tek bir öykünün yaşamın tüm olasılıklarını kapsayamayacağı kabul edildiğinden, alternatif açıklamalara yer vermeyen öykülerin tehlikeli olabileceği düşünülür. $\mathrm{Bu}$ nedenle çoklu açıklamalara ihtiyaç duyulur (Doan 1997).

Postmodernizmle ilişkili önemli kavramlardan birisi de sosyal inşacılıktır. Birçok farklı tanı$\mathrm{m}$ olmasına rağmen temel olarak sosyal inşacılık, gerçekliğin keşfedilen değil, sosyal süreçlerin 
sonucunda oluşturulan bir fenomen olduğunu öne sürer. Buna göre bilgi, bireylerin belli bir sosyal ve kültürel yapının içerisindeki etkileşimleri sonucu ortaya çıkar ve bireylerin sosyal etkinliklere katılmasıyla inşa edilir (Kim 2001). Sosyal inşacılığın odak noktası bilgilerin ve tutumların zaman içinde çeşitli kültürel ve toplumsal bağlamlarda nasıl geliştiğidir (Burr 2012). Psikoloji perspektifinden bakıldığında ise sosyal inşacılık; insanın verili bir özünün olmadığını, sosyal ilişkilerdeki etkileşimin bir ürünü olduğunu kabul eder. Bu varsayımdan hareketle, bireyleri anlamak için onların "içine" (tutum, biliş vs.) değil, insanlar arası etkileşime odaklanılması gerektiğini öne sürer (Burr 2012). Öte yandan bu etkileşim sürecinde geliştirilen bazı açıklamalar cinsiyet, ırk ve bölge gibi farklılıklara duyarlı olmadığında, bu açıklamalara uymayan insanların marjinalleştirilme tehlikesi ortaya çıkar. Bu nedenle öyküsel terapide uzman görüşlerine değil, bireylerin öznel deneyimlerine daha fazla önem verilir (Doan 1997).

\section{Öyküsel Terapinin Kuramsal Temeli}

Öyküsel terapi, Michael White ve David Epston'un 1980'li yıllardaki çalışmalarından doğmuştur (Tarragona 2008). Bu yaklaşımın ortaya çıkmasında, Michael Foucault, Erving Goffman ve Gregory Bateson gibi düşünürlerin fikirleri oldukça etkili olmuştur (Nichols 2013; White \& Epston 1990). Özellikle Foucault'nun (2016) bilgi ve iktidar süreçleri arasında kurduğu bağlant1, öyküsel terapinin kuram ve uygulamalarını derinden etkilemiştir. Psikolojik bilgi süreçlerinin altında yatan ideolojik, politik varsayımlar sorgulanmış ve bu varsayımlar terapi süreçlerinin merkezine alınmıştır (Madigan 2016). Bu noktada öyküsel terapide ideoloji ve dil arasındaki ilişki önem kazanmıştır. Kelimelerin yaşam deneyimi üzerindeki etkisi göz önünde bulundurularak, terapi sürecinde dile özel bir vurgu yapılmıştır. Bu etkinin kelimelerin nasıl kullanıldıklarına bağlı olarak olumlu veya olumsuz şekilde yorumlanabileceği öne sürülmüştür (Rivett, Buchmüller \& Oliver 2018). Bu açıdan dilin yorumlanması yaklaşımın temel bileşeni olarak kabul edilmiştir.

Foucault'un iktidar ve bilgi ilişkisine yönelik fikirlerinden hareketle; öyküsel terapide insanların sahip oldukları hikayelerin, egemen ideolojiler tarafından belirlendiği öne sürülmüştür (Madigan 2016). Buna göre; ruh sağlığ1 profesyonellerinin, danışanlara ve psikolojik uygulamalara yönelik fikirleri çeşitli iktidar ilişkilerinin bir ürünüdür. Öyküsel terapistler, geleneksel terapi yaklaşımlarının, büyük egemen kurumlar (örn. bilim, medya ve psikiyatri) tarafından yaratılmış ve sorgusuz sualsiz kabul edilmiş varsayımlara dayandığını öne sürer (Madigan 2016). Bu nedenle, bireylerin yaşadıkları sorunları onların "içinde" ve "bedeninde" gören geleneksel yaklaşıma şiddetle karşı çıkılmış ve yaşanan sorunlar, birey ile toplumsal pratikler arasındaki ilişkilere yerleştirilmiştir (White \& Epston 1990).

\section{Öyküsel Terapinin Varsayımları}

Öyküsel terapi benliği tek başına bağımsız bir fenomen olarak değil, ilişkinin bağlamı içinde ele alır. İnsanları ve yaşadıkları sorunlarını anlamada bireycilik yerine ilişkiselliği tercih etmek, bu yaklaşımın en temel özelliklerindendir (Madigan 2016). Bu temel bireycilik karşıtlığının yanında Morgan (2000) öyküsel terapinin bir dizi varsayıma sahip olduğunu öne sürmektedir:

1. Sorun, sorundur. Kişiler sorun değildir.

2. Sorunlar her zaman ortaya çıkmaz. Diğer bir deyişle, sorun her zaman mevcut değildir.

3. Yaşam deneyimlerimize yönelik bakış açımız zaman içerisinde değişir.

4. Sorunlar kültürel bağlamlarda inşa edilir.

5. Tek bir doğru yoktur, çoklu doğrular vardır.

6. İnsanlar kendi yaşamlarının uzmanıdırlar ve sorunlarını çözmekte kendilerine yardımcı olacak yeteneklere sahiptirler.

7. Terapist, kendisini uzman veya otorite olarak konumlandırmamalıdır. 
8. Terapötik dokümanların ve ritüellerin kullanımı, değişimin sürdürülmesinde değerli birer kaynaktır.

\section{Öyküsel Terapi Açısından İnsan ve Sorunları}

Öyküsel terapi danışanların hikayelerine, bu hikayelerin içinde oluşturulmuş yaşam temalarına, bu temalarla ilişkili anlamlara yönelik tepkilere odaklanır (Semmler \& Williams 2000). Buna göre, insan ve sorunları söz konusu olduğunda evrensel doğrulardan, ilkelerden ve söylemlerden söz edilemez (Gladding 2012). İktidar ve tahakküm aracı olarak kullanılma potansiyeli olduğundan, normal-anormal, hastalık-sağlık gibi kategoriler reddedilir (Nichols 2013). Bunun yerine, sorunların kaynağı, bireyin deneyimini yeterince yansıtmayan, yetersiz ve kısıtlayıcı hikayeler olarak görülür (White \& Epston 1990). Sorun-doyumlu (problem-saturated) olarak adlandırılan bu hikayeler, toplum tarafindan danışanlara dayatılır ve danışanlar hayatlarını bu hikayeler üzerinden anlamlandırır. Dayatılan bu hikayeler, danışanların yaşamları üzerindeki kontrolü kaybetmelerine neden olur (Shapiro \& Ross 2002).

Aile terapisi bağlamında değerlendirildiğinde hikayeler aileler için de önemlidir, çünkü aileler hikayeler sayesinde hayatlarına, ilişkilerine anlam verir ve onları şekillendirir. Yaşanan problemlerin, ailelerin nasıl davranması gerektiğini dayatan ve doğru olarak kabul edilen bir kültürel bağlamın ve söylemin etkisinin sonucu olduğu öne sürülür (Dickerson 2016). Sistem yaklaşımı, yapısal aile terapisi ve stratejik aile terapisi gibi geleneksel terapi yaklaşımları, sorunların aile sistemindeki uyumsuz etkileşimlerden kaynaklandığını öne sürerken (Özgüven 2017); öyküsel terapi problemlerin ailelerin içinde olduğu ya da onların bir şekilde yetersiz olduğu fikrine karşı çıkar. Problemli durumlar, ailelere dayatılan hikayelerle, ailelerin deneyimleri uyuşmadığı zamanlarda ortaya çıkar (Carr 1998).

\section{Terapistin Konumu ve Terapi Süreci}

Öyküsel terapide, terapist kişilik özelliklerini ve sorunları nesnel bir şekilde tanılayan bir otorite rolünü oynamaz. Bunun yerine işbirlikçi ve eşitlikçi bir konum benimseyerek danışanlara yardım etmeye çalışır (Goldenberg, Stanton \& Goldenberg 2017). White (2000) terapistin konumunu, "merkezde olmayan fakat etkili" olarak tanımlamıştır. Danışanın deneyimlerinin ve gündeminin terapi sürecinde öncelikli olması anlamında terapist merkezde değildir. Öte yandan, sorduğu sorular konuşmanın nasıl devam edeceğini etkilediği için terapist etkilidir (Tarragona 2008). Öyküsel terapist, terapi sürecinde standart değerlendirme araçları ve ölçülebilir tanı kriterleri kullanmaz. Bunun yerine, problemler hakkında bilgi elde etmek için en iyi kaynak olarak danışanları görür ve onların tanımlamalarına önem verir. Ayrıca, değerlendirme sürecini hikaye anlatımının/yeniden anlatımının bir parçası olarak görür ve sorunların nedenlerine değil, bu sorunların bireyleri veya aileleri nasıl etkilediğine odaklanır (Anderson 2016).

Öyküsel terapide sorunların bir işlevinin olduğu kabul edilmez. Bunun yerine, sorunlar bireylerin veya ailelerin hayatlarını olumsuz etkileyen ve bir an önce çözülmesi gereken şeyler olarak görülür (Gladding 2012). Dahası danışanların sorunlarını çözebilecek ve yaşamlarını değiştirebilecek güce sahip olduğu varsayılır. Bu nedenle terapistler; sorunları çözen kişiler olarak değil, danışanların baskıcı ve sorun yaratan kültürel pratiklerden kurtulmasına yardımcı olan kişiler olarak görülür (Nichols 2013). White'a göre (1995) öyküsel terapi sürecinin temel uygulamaları aşağıdaki gibidir:

- İşbirlikçi bir tutum benimsemek.

- Danışanların kendilerini sorunlardan ayrı görmelerine yardımcı olmak.

- Sorunların ortaya çıkmadığı durumlar olarak tanımlanan eşsiz sonuçları (unique outcome) araştırmak ve soruları kullanarak danışanların bu eşsiz sonuç tanımlamalarını güçlendirmek. 
- Eşsiz sonuçlar ile geçmişteki diğer olaylar arasında bağlantı kurmak ve benliğin sorundan daha güçlü görüldüğü alternatif ve tercih edilen bir kişisel hikaye geliştirmek.

- Danışanın sosyal ağlarındaki diğer önemli kişileri, geliştirilen bu yeni öz anlatıya (self-narrative) dahil etmek.

- Yeni öz anlatıyı destekleyen bilgileri ve pratikleri, edebi araçları kullanarak belgelemek.

- Benzer baskıcı hikayeler tarafından kapana kısılmış diğer kişilerin yeni bilgilerden yararlanmalarını sağlamak.

Bu doğrultuda öyküsel terapi süreci üç aşamadan oluşur: Baskın kültürel hikayenin çözülmesi, problemin dıșsallaștırılması ve hikayenin yeniden yazılması (Semmler ve Williams 2000). İlk aşamada danışanlar, sosyal yapıdaki ve ilişkilerdeki güç temelleri üzerine ve baskın hikayelerin hayatlarını nasıl etkilediği üzerine düşünmeye davet edilir. Bir sonraki aşamada "Sorun, sorundur. Kişiler sorun değildir." (White \& Epston 1990) ilkesinden hareketle, danışanın deneyimlediği sorunların dişsal kaynaklı olduğu kabul edilir ve sorun ile danışan birbirinden ayrılır. Son aşama olan hikayenin yeniden yazılmasında ise danışanlar, itibarlarına ve öz-değerlerine zarar vermeyen yollar bulmaya çalışır. Bu süreç, eşsiz sonuçları ortaya çıkararak ve bunlara anlam vererek kolaylaştırılır (Molina, Estrada \& Burnett 2004). Bu bahsedilen temel hedeflere ulaşabilmek amacıyla da birçok terapötik teknik kullanılır. Bir sonraki bölümde bu teknikler kısaca özetlenecektir.

\section{Terapi Teknikleri}

Soruları Kullanma: Tüm terapi ekollerinde olduğu gibi öyküsel terapide de sorular terapi sürecinin en önemli bileșenlerinden birisidir. Sorular, sorunların belirlenmesinde ve başa çıkma kaynaklarının incelenmesinde kullanılır. Bu yaklaşımda öne çıkan soru şekli istisna (exception) ve manidarlık (significance) sorularıdır. İstisna sorularıyla, sorunların her zaman ortaya çıkmadığ1 varsayımından hareketle yerleşik problemlerin ve hikayelerin yaşanmadığı durumları belirlemek amaçlanır. Örneğin, "Bana problemin ortaya çıkmasını engellediğiniz bir andan bahseder misiniz?" gibi bir soru istisnai durumların ortaya çıkarılması için kullanılabilir. Bu tip sorularda amaç, danışanların temel inançlarını zayıflatmak ve sorunun çözülmesine yönelik umut aşılamaktır. Manidarlık soruları ise belirlenen istisnaların, danışan ve aile açısından anlamını ve önemini ifade etmeye yönelik sorulardır. Bu anlamlandırma süreci daha sağlıklı hikayelerin geliştirilmesi için bir adım olarak işlev görür (Gladding 2012). "Çocuğunuzun hafta sonu hiç öfke nöbeti geçirmemesi sizin için ne anlama geliyor? Bu durum çocuğunuz ve aileniz hakkında bize ne anlatır?" gibi bir soru manidarlık sorularına örnek olarak verilebilir.

Problemin Dışsallaştırılması: Semmler ve Williams (2000) tarafından terapi sürecinin bir aşaması olarak da kavramsallaştırılan problemin dışsallaştırılması tekniği, öyküsel terapinin en özgün yöntemlerinden birisidir (Madigan 2016). Bu teknik sayesinde aile üyelerinin yaşamları ve ilişkileri, sorun-doyumlu tanımlamalarından ayrıştırılmaya çalışılır. Örneğin, anoreksiya nervozası olan danışana "Anoreksia nevroza hayatınıza nasıl zarar veriyor?" diye sorularak problem dişsallaştırılır. Böylelikle danışanın kişiliği ile problem birbirinden ayrılır (Carr 1998). Problemin dışsallaştırılması tekniği danışanlara kendilerini yeniden tanımlama ve problem odaklı bakış açısından çıkarak yeni bir hikaye geliştirme şansı yaratır. Böylelikle, ne kişilerin ne de ilişkilerin kendisi problem olarak görülür (White \& Epston 2005). Bu uygulamalarda sorunlar, ailenin ilişkilerini ve yaşamını olumsuz şekilde etkileyen dışsal bir şey olarak görülür. $\mathrm{Bu}$ da aile üyelerinin birbirlerini suçlamasını azaltarak, çözüme yönelik adım atmasını kolaylaştırır (Gladding 2012). Problemin dışsallaştırılması, kişilerin baskın hikayelerden kendilerini ayırmalarına yardımcı olur. Bunun yanında, sorunlar bireylerin bir parçası olarak değil, onları 
istila etmeye çalışan şeyler olarak kavramsallaştırılır. Bu sayede bireylerin yaşadıkları sorunlar hakkında kendilerini suçlamalarının önüne geçilmeye çalışılır (Nichols 2013).

Danışanlar ile sorunlar birbirinden ayrıldıktan sonra sorunların kişilerin üzerindeki etkileri sorgulanır. Böylelikle, danışanların bir soruna sahip oldukları düşüncesi yerine, sorunların danışanlara sahip olmaya çalıştıkları anlayışı yerleştirilmeye çalış1lır. Örneğin, fobilerden muzdarip olan bir çocuğa "Korku"nun ona istediklerini nasıl yaptırdığı ve buna karş1 çocuğun başa çıkmak için neler yaptığı sorgulanır (Nichols 2013). Öte yandan, bireylerin yaşadıkları sorunların dışsallaştırılması, kendi sorumluluklarını göz ardı etmeleri anlamına gelmez. Aksine, bu uygulamalar problemle olan ilişkilerini tanımlamalarına ve farkındalık kazanmalarına yardımcı olur. Davranışların dışsallaştırılması kişinin problem-doyumlu tanımlamalarından özgürleşmesini sağlayarak, kişileri yeni hikayeler geliştirmeleri konusunda sorumluluk almaya teşvik eder (White \& Epston 1990). Özetle, bu teknik bir anlamda bireyi ve onun bedenini nesneleştiren kültürel pratiklere karşı bir karşıt-pratik (counter-practices) geliştirme sürecidir. Bu süreç bireylerin kendilerini yeniden oluşturmalarına yardımcı olur, yeni bilgi ve hikaye örüntüleri geliştirmelerini sağlar (White \& Eptson 1990).

Kimin Sorumlu Olduğu Konusunda Farkındalık Kazanma: Problemin danışan üzerindeki etkisinin ve danışanların problem üzerindeki etkisinin incelenmesi örtük bir şekilde bu iki fenomenin birbirinden ayrı olduğuna işaret eder (White \& Epston 1990). Sorunlar dişsallaştırıldıktan sonra, danışanın ya da ailenin soruna yönelik farkındalığını arttırabilmek amacıyla bu kişileştirilmiş/dışsallaştırılmış sorunların, bireyin hayatı ve ilişkileri üzerindeki etkileri araştırılır. Bireylerin bu sorunları çözme konusunda, kendi potansiyellerini değerlendirebilmeleri adına, sorunlara nasıl tepki verdikleri ve hem kendilerinin hem de ailelerin, sorunları nasıl etkiledikleri de araştırılır (Gladding 2012). Böylelikle "sorunlu insan" anlayışından, "sorunlarla ilişkisi olan insan" anlayışına doğru geçilir (Carr 1998). Öyküsel terapide, soruların bu şekilde kullanılmasına göreli etki soruları (relative influence questioning) denir (Freedman \& Combs 1996). "Depresyon sorunu sizi nasıl etkiliyor?" ve "Sizin depresyon üzerindeki etkileriniz nelerdir?" soruları bu yönteme örnek olarak gösterilebilir.

Mektupları Kullanma: Yazılı şeylerin -sözlü etkileşimlerle karşılaştırıldığında- daha güvenilir, daha kolay kabul edilebilir, yanlış anlaşılmaya daha az müsait olması ve tekrar tekrar okunabilmesi, öyküsel terapistleri yazılı materyaller kullanmaya teşvik eder (Abels ve Abels 2001). Terapi sürecinde yaşananların gerçek hayatta devamlılığını sağlamak, bu süreçte yaşananların hatırlanmasını kolaylaştırmak ve terapist için klinik notlar olarak kullanılabilmesi amacıyla terapistler mektupları kullanırlar (Gladding 2012). Mektupların terapist ve danışanlar arasındaki hiyerarşiyi azaltacağı ve böylelikle terapötik işbirliğini kolaylaştıracağı varsayılır (Kindsvatter, Nelson \& Desmond 2009). Terapistler mektup yazarken, önceki seansla bağlantı kurmaya, sorunlar ve danışan arasındaki karş1lıklı etkileşime ve danışana özel spesifik sonuçlar ve durumlar üzerine odaklanmaya dikkat eder (Kesici et al. 2017).

Kutlamalar ve Sertifika Verme: Öyküsel terapi sürecinde, terapi odasında yapılan çalışmaların danışanın "dışarıdaki gerçek hayatına" yayılması ve terapi bittiğinde kat edilen ilerlemenin sürdürülebilmesi amacıyla mektuplara ek olarak, çeşitli dokümanlar ve etkinlikler kullanılmaktadır (Payne 2006). Danışanla birlikte hazırlanan bu sertifikalar, danışanın problemlerini, bu problemlerin çözümü için kullanılan stratejileri ve terapi sonucunda elde ettiği kazanımları içerir. Ek olarak; terapi yapılan kurumun adı, terapistin ismi ve imzası gibi bilgiler de bulunur. Bu sertifikalar danışanların arkadaşları ve ailelerinin de katıldığı kutlamalarla danışanlara verilir (Gladding 2012; Payne 2006).

Yaşanan sorunlar bireyin sevgi, anlayış ve destek kaynakları olan sistemlerle ilişkilerini zayıflatabilir, sosyal ve psikolojik açıdan izole duruma düşürebilir. Mektup yazma uygulama- 
larının amaçlarından biri de bu zarar görmüş bağları onarmak ve yeniden etkinleştirmektir (Madigan 2016). Bu süreçte terapist danışanla birlikte danışanın belirlediği bir kişiye mektup yazar. Bu mektupla bu kişiden, danışanla olan ilişkilerine dair anılarını, danışan için beslediği umutları ve danışanla olan ilişkilerinin geleceğine yönelik tahminleri paylaşmasını ister (Madigan 2016). Böylelikle danışanın kendine ilişkin temsillerinin ve sorun doyumlu hikayesinin değiştirilmesi amaçlanır. Yukarıda bahsedilen amaçların dışında mektuplar, terapinin bitiş sürecini hızlandırmak ve bir terapi seansından sonra terapistin aklına gelen düşünceleri unutmadan danışanlarıyla paylaşabilmesi gibi farklı birçok amaç için de kullanılabilmektedir (White \& Epston 1990).

Terapi sürecinde ihtiyaca göre farklı türde mektuplar da kullanılır. Terapist, terapiye katılmaya istekli olmayan danışanların terapiye katılımını sağlamak için davet mektuplarını kullanılırken, seanslardaki sorun-doyumlu hikayeye alternatif olabilecek noktaları özetleyen özet mektupları da kullanabilir. Bu özet mektuplar her seanstan sonra danışana gönderilir (Goldenberg, Stanton \& Goldenberg 2017). Terapinin sonunda danışanın veya ailenin geleceğiyle veya ilişkileriyle ilgili terapistin tahminlerini içeren tahmin mektupları; bir uzman olarak terapistin danışan veya aile hakkındaki fikirlerini içeren referans mektupları; danışanları bunaltan ve altından kalkamadıkları bazı özel durumların (örn. ölen kardeşinin cenazesine katılmak) çözümünde yardımcı olması amacıyla kullanılan özel durum mektupları öyküsel terapide kullanılan diğer mektup türleridir (Carr 1998; White \& Epston 1990).

Hikayeyi Baştan Yazma: Terapi sürecinin temel amacı, danışanları kısıtlayan baskın hikayelerin yapı-bozumuna uğratılıp, danışanların deneyimlerini daha iyi yansıtan hikayelerin geliştirilmesidir (Gladding 2012; Nichols 2013). Sorun olan baskın hikaye ile danışan birbirinden ayrılarak yeni bir hikaye yazımı için alan yaratılır. Bu alan yaratma sürecinde, dışsallaştırma konuşmaları önemli bir rol oynar. Buna göre; geleneksel terapilerdeki, sorunları danışanın bedeninin içinde konumlandırma yaklaşımının altında yatan bağlamsal ve kültürel zeminler dışsallaştırma konuşmaları üzerinden sorgulanır. Böylelikle bireyler, baskın hikayeler üzerinden öngörülemeyecek olan, deneyimlerin ihmal edilen hayati yönlerini belirleyebilir (Madigan 1992). Ayrıca, öyküsel terapide kullanılan dil ve tanımlamalar da bu süreci kolaylaştırır. Örneğin, anoreksiya kelimesinin danışanın doğasında var olan bir sorunu tarif ettiğini düşünülmez ve "anoreksik danışan" diye bir ifade kullanılmaz. Aksine, sorundan muzdarip olan kişi anokreksiya ile söylemsel bir ilişki içinden görülür. Öyküsel terapi açısından anokreksiya insan bedenine yönelik, kapitalizm sonrası ortaya çıkan siyasete karşı verilen bir yanıt olarak değerlendirilir (Madihan 2016). Böyle bir temel duruş, yeni hikaye yazımına zemin hazırlar. Baskın hikayeye uymayan bazı deneyimler (sorunların ortaya çıkmadığı durumlar), eşsiz sonuçlar olarak adlandırılır ve bu istisnai durumlar, danışanın alternatif hikaye geliştirme süreci açısından verimli bir kaynak sağlar (Payne 2006). Eşsiz sonuçların, danışanın kendisi, diğerleri ve ilişkileri açısından ne anlama geldiği üzerinde durularak, alternatif hikaye geliştirme süreci desteklenir (White \& Epston 1990). Örneğin, öfke problemi olan bir danışanın dikkati, öfkesini sağlık11 bir şekilde düzenleyebildiği geçmiş örneklere çekilir ve bu örneklerin danışanla ilgili neler söylediği araştırılır. "Bu örneklerde öfkenin üstesinden gelebilmeniz kişiliğiniz hakkında neler söylüyor?" gibi bir soru hikaye yazım sürecini destekleyebilir. Bu kapsamda değerlendirildiğinde tüm terapi süreci aslında hayatı ve ilişkileri yeniden yazma sürecidir.

\section{Öyküsel Terapinin Etkililiğine Yönelik Çalışmalar}

Son yıllarda psikoterapi alanında, teori ve pratiği bütünleştirerek ve deneysel olarak desteklenmiş uygulamaları yaygınlaştırarak, bireylerin aldıkları ruh sağlığı hizmetinin kalitesini artırmayı amaçlayan kanıt temelli yaklaşımların önem kazandığı görülmektedir (APA Presidential Task Force on Evidence-Based Practice 2006). Bu gelişmeyle birlikte psikoterapi araştırmalarında farklı terapi yöntemlerinin, çeşitli gruplarda ve sorunlarda etkililiklerinin incelenmesine ve 
terapi sonuçları üzerinde etkili olan faktörlerin (örn. danışan özellikleri, sorunun şiddeti vs.) belirlenmesine yönelik çalışmalar hız kazanmıştır (Kazdin 2008; David, Lynn \& Montgomery 2018). Öte yandan, öyküsel terapistler ise uzunca bir süre yaptıkları terapilerin etkililiğine yönelik çok fazla çalışma yürütmemişlerdir. Madigan'a (2016) göre; terapi uygulamalarını değerlendirmeye yönelik çalışmaların eksikliği kısmen, öyküsel terapistlerin bilimsel olarak addedilen her şeye ve yaşanan deneyimi sayılara çevirmeye yönelik girişimlere mesafeli olmalarından kaynaklanmaktadır. Yapılan etkililik çalışmalarının da genellikle vaka analizi düzeyinde kaldığı görülmektedir. Fakat kanıt temelli uygulama yaklaşımının da muhtemel etkisiyle, son yıllarda öyküsel terapinin farklı sorunlardaki uygulamalarını değerlendirmeye yönelik daha nitelikli çalışmaların arttığı gözlenmektedir. Bu bölümde öyküsel terapilerin etkililiğini araştıran deneyler ve yarı deneysel çalışmalar gözden geçirilecektir.

Yapılan çeşitli çalışmalar, öyküsel terapinin, depresif belirtilerin azaltılmasında danışanlara yardımcı olabileceğini göstermektedir. Öyküsel terapinin depresyon ve yalnızlık belirtileri üzerindeki etkililiğinin incelendiği bir araştırmada, terapi alan gruptaki katılımcıların depresyon ve yalnızlık puanlarının, kontrol grubundan anlamlı düzeyde düşük olduğu bulunmuştur (Dastbaaz et al. 2014). Başka bir çalışmada depresyon tanılı bireylerde öyküsel terapi ve bilişsel davranış̧̧ı terapinin (BDT) etkililiği karşılaştırılmıştır. Çalışma sonucunda her iki terapi yönteminin de depresif belirtileri anlamlı şekilde azalttığ yapılan izlem çalışmasında (Lopes et al. 2014b) her iki terapi grubundaki danışanların yaklaşık 1/3'ünün terapi kazanımlarını sürdürdüğü bulunmuş ve iki grubun izlem sonuçları arasında anlamlı bir farklılık gözlenmemiştir. Bu bulgular, depresif belirtiler açısından öyküsel terapinin uzun vadede de BDT ile karşılaştırılabilir düzeyde etkili olduğuna işaret etmektedir. Depresyon tedavisinde etkili olduğu birçok çalışmayla gösterilmiş olan ve sıklıkla ilk tedavi seçeneği olarak görülen BDT ile öyküsel terapinin benzer etkinliğe sahip olduğunun gösterilmesi önemli bir bulgudur. Bir diğer çalışmada da depresyon tanısı almış bireylerde öyküsel terapinin depresif belirtileri azaltmada etkili olduğu ve 3 aylık izlemde bu etkinin korunduğu bulunmuştur (Vromans \& Schweitzer 2011).

Depresyonun yanı sıra, öyküsel terapinin kaygı bozukluklarında da kullanılmaya başlandığı görülmektedir. DSM-5 (2013) yayınlanana kadar travma sonrası stres bozukluğu (TSSB) ve obsesif kompulsif bozukluk (OKB) birer kaygı bozukluğu olarak kabul edildiği ve bazı etkililik çalışmaları bu tarihten önce gerçekleştirildiği için bu iki bozukluk da bu başlık altında incelenmiştir. TSSB tanısı almış gazilerle yapılan bir pilot çalışmada terapiyi tamamlayan katılımcıların 3/11'ü TSSB tanısını karş1lamaz olmuş ve toplamda 7 katılımcının belirtilerinde klinik olarak anlamlı düşüş gözlenmiştir (Erbes et al. 2014). OKB hastalarıyla yapılan çalışmada, bekleme listesi ile karşılaştırıldığında öyküsel terapi grubundaki danışanların OKB belirtileri, hem tedavi sonrasında hem de tedavinin sonlanmasından 2 ay sonra yapılan izlem ölçümünde anlamlı olarak daha düşük bulunmuştur (Esfahani et. al. 2015).

Daha önce de belirtildiği gibi öyküsel terapi diğer ana akım terapi yaklaşımlarıyla karşılaştırıldığı zaman, göreceli olarak daha az bilinen bir terapi yöntemidir. Nitekim, Türkçe literatür gözden geçirildiğinde öyküsel terapi ile ilgili yalnızca birkaç gözden geçirme makalesine ve terapi etkililiğini araştıran iki tez çalışmasına ulaşılmıştır. Bu çalışmalardan birinde ergenlerde öyküsel terapinin kaygı ve irade etkisi incelenmiştir. Çalışma sonucunda öyküsel terapinin kaygı puanlarında anlamlı bir düşüş sağladığı belirlenirken, irade açısından bir farklılık gözlenmemiştir (Koca 2018). Yine ergenlerle yapılan benzer bir çalışmada öyküsel terapi grubundaki katılımcıların psikolojik dayanıklılık puanlarının kontrol grubundan yüksek olduğu ve yaklaşık 4 ay sonra yapılan izlem ölçümünde terapi kazanımlarının korunmaya devam ettiği anlaşılmıştır. $\mathrm{Bu}$ sonuçlar öyküsel terapinin ergenlerde psikolojik dayanıklılı̆g 1 güçlendirmede yararlı olabileceğine işaret etmektedir (Yazıcı 2018). 


\section{Sonuç}

Hızlı bir şekilde gelişen teknoloji, değişen ve giderek karmaşıklaşan toplumsal yapı, geleneksel değerlerin ve hikayelerin eski gücünü yitirmesi bireylerin kimlik duygularını sarsmakta ve bireyleri anlam arayışına itmektedir. Sayar'ın (2013) da belirttiği gibi günümüzde terapi için başvuran danışanlar daha çok hedef, ideal ve değer yoksunluğu gibi benlik sorunlarından yakınmaktadır. İstikrarlı ideolojilerin veya değerlerin eksikliği bireylerin yaşadıkları bu benlik sorunlarını şiddetlendirmektedir. Bu bağlamda hayatı, hikayelerimiz aracılığıyla anlamlandırdığımızı öne süren ve bireylerin, deneyimlerini daha iyi temsil eden hikayeler geliştirmesine yardımcı olmaya çalışan öyküsel terapi günümüz insanı için önemli bir seçenek olabilir. Birçok etnik ve dini farklılığı bünyesinde barındıran ülkemizde, güç ve iktidar ilişkilerini terapi ortamına getirmek ve toplum tarafından dayatılan baskın hikayelerle mücadele etmek gibi öyküsel terapinin temel ilkeleri, terapi uygulamalarında özellikle önemli olabilir.

Hem kuramsal alanda hem de uygulamada danışanların hayatlarını çevreleyen iktidar ilişkilerini sorgulaması, terapi sürecinde kendine has teknikler kullanması (örn. mektup yazma, sertifika verme vs.) öyküsel terapiyi yaygın terapi yöntemlerinden farklı bir yere koymaktadır. Bireysel, grup veya aile terapisi olarak uygulanabilmesi, tanısal kategorilerden çok danışanların deneyimlerine vurgu yapması ve kültürel ve toplumsal farklılıklara özellikle duyarlı olması öyküsel terapinin önemli avantajlarındandır. Öte yandan, son dönemde kanıt temelli terapi yaklaşımlarının ön plana çıktığı düşünülürse, öyküsel terapi uygulamalarının hangi kişilik özelliklerine sahip danışanlarda ve ne tür sorunlarda etkili olduğuna ve bu etkililiğin uzun vadede nasıl bir seyir izlediğine yönelik çalışmaların yapılmasına ihtiyaç vardır. Bireylerin yaşadıkları farklı sorunlarda etkili olduğunun gösterilmesi bu terapi yaklaşımının kullanımını yaygınlaştırabilir. 


\section{KAYNAKÇA}

Abels, P. \& Abels, S. L. (2001). Understanding narrative therapy: A guidebook for thesocial. Springer series on social work. Springer Publishing Company.

American Psychological Association, Presidential Task Force on Evidence-Based Practice. Evidencebased practice in psychology. American Psychologist 61/4 (2006) 271-285.

Anderson, H. (2016). Postmodern/poststructural/social construction therapies. Handbook of family therapy. New York 2016.

APA (2013) Diagnostic and Statistical Manual of Mental Disorders (DSM 5). Washington, DC, American Psychiatric Association.

Besley, A. C. (2002). "Foucault and the turn to narrative therapy". British Journal of Guidance and Counselling 30/2 (2002) 125-143. doi: 10.1080/03069880220128010.

Burr, V. (2012). Sosyal İnşacılık. Çev.: S. Arkonaç, Ankara 2012 (Orijinal çalışma basım tarihi 2003).

Carr, A. (1998). "Michael White's narrative therapy”. Contemporary Family Therapy 20/4 (1998) 485503. doi: 10.1023/A:1021680116584.

Çelik, H. (2017). "Psikoterapide yeni soluk: öyküsel terapi". e-Kafkas Eğitim Araştırmaları Dergisi 4/1 (2017) 34-50.

Dastbaaz, A., Yeganehfarzand, S., Azkhosh, M., \& Shoaee, F. (2014). The Effect of group counseling "Narrative Therapy" to reduce depression and loneliness among older women. Iranian Rehabilitation Journal XII/20 (2014) 11-15.

David, D., Lynn, S. J., \& Montgomery, G. H. (Eds.). (2018). Evidence-based psychotherapy: The state of the science and practice. John Wiley \& Sons 2018.

Dickerson, V. (2016). What Is Narrative Therapy? Poststructural and Narrative Thinking in Family Therapy Practice. Poststructural and Narrative Thinking in Family Therapy. Switzerland 2016.

Doan, R. E. (1997). "Narrative therapy, postmodernism, social constructionism, and constructivism: Discussion and distinctions". Transactional Analysis Journal 27/2 (1997) 128-133. doi:10.1177/ 036215379702700208.

Doan, R. E. (1998). "The king is dead; long live the king: Narrative therapy and practicing what we preach". Family process 37/3 (1998) 379-385.

Erbes, C. R., Stillman, J. R., Wieling, E., Bera, W., \& Leskela, J. (2014). "A pilot examination of the use of narrative therapy with individuals diagnosed with PTSD”. Journal of traumatic stress 27/6 (2014) 730-733.

Esfahani, M., Kjbaf, M. B., \& Abedi, M. R. (2015). "Evaluation and comparison of the effects of time perspective therapy, acceptance and commitment therapy and narrative therapy on severity of symptoms of obsessive-compulsive disorder". Journal of the Indian Academy of Applied Psychology 41/3 (2015) 148-155.

Foucault, M. (2016). Özne ve iktidar: Seçme yazılar-2. Çev. I. Ergüden ve O. Akınhay. İstanbul 2016.

Freedman, J. \& Combs, G. (1996). Narrative therapy: The social construction of preferred realities. New York-London 1996.

Gladding, S. T. (2012). Aile terapisi: Tarihi, kuram ve uygulamaları (5. Baskı). Çev.: İ. Keklik \& İ. Yildırım. Ankara 2012.

Goldenberg I., Stanton, M. \& Goldenberg, H. (2017). Family therapy: an overview (9. Bask1). USA 2017.

İlgar, S. C., \& İlgar, M. Z. (2018). “Öyküsel terapi ve psikolojik danışmada kullanımı”. Electronic Turkish Studies 13/19 (2018) 939-954.

Karaırmak, Ö., \& Bugay, A. (2016). "Postmodern diyalog: Öyküsel psikolojik danışma”. Türk Psikolojik Danışma ve Rehberlik Dergisi 4/33 (2016) 24-36.

Kazdin, A. E. (2008). "Evidence-based treatment and practice: new opportunities to bridge clinical research and practice, enhance the knowledge base, and improve patient care". American psychologist 63/3 (2008) 146-159.

Kesici, Ş., Mert, A., Girgin Büyükbayraktar, Ç. \& İlgün, Es. (2017). Aile terapisinde kullanılan teknikler. Ankara 2017. 
Kim, B. (2001). "Social constructivism". Ed. M. Orey, Emerging Perspectives on Learning, Teaching, and Technology 1/1 (2001) 16.

Kindsvatter, A., Nelson, J. R., \& Desmond, K. J. (2009). "An invitation to between-session change: The use of therapeutic letters in couples and family counseling". The Family Journal 17/1 (2009) 32-38.

Koca, M. (2018). Narrative terapi temelli grupla psikolojik danışma programının ergenlerin irade ve kaygı düzeylerine etkisi. Yayımlanmamış yüksek lisans tezi. Hasan Kalyoncu Üniversitesi, Gaziantep.

Lopes, R. T., Gonçalves, M. M., Machado, P. P., Sinai, D., Bento, T., \& Salgado, J. (2014a). Narrative Therapy vs. Cognitive-Behavioral Therapy for moderate depression: Empirical evidence from a controlled clinical trial. Psychotherapy Research 24/6 (2014) 662-674.

Lopes, R. T., Gonçalves, M. M., Fassnacht, D. B., Machado, P. P., \& Sousa, I. (2014b). "Long-term effects of psychotherapy on moderate depression: A comparative study of narrative therapy and cognitive-behavioral therapy". Journal of affective disorders 167 (2014) 64-73.

Madigan, S. (2016). Naratif Terapi. Çev. G. Akkaya. İstanbul 2016.

Madigan, S. P. (1992). "The application of Michel Foucault's philosophy in the problem externalizing discourse of Michael White". Journal of Family Therapy 14/3 (1992) 265-279.

Molina, B., Estrada, D., \& Burnett, J. A. (2004). "Cultural communities: Challenges and opportunities in the creation of "happily ever after" stories of intercultural couplehood". The Family Journal 12/2 (2004) 139-147. Doi: 10.1177/1066480703261962.

Morgan, A. (2000). What is narrative therapy? Adelaide 2000.

Nichols, P. M. (2013). Aile terapisi kavramlar ve yöntemler. Çev. O. Gündüz. İstanbul 2013.

Özgüven, İ. E. (2017). Evlilik ve aile terapisi (4. Baskı). Ankara 2017.

Parry, A., \& Doan, R. E. (1994). Story re-visions: Narrative therapy in the postmodern world. Guilford Press 1994.

Payne, M. (2006). Narrative therapy: An introduction for counsellors (2. basim). London 2006.

Polkinghorne, D. E. (2004). Narrative therapy and postmodernism. The handbook of narrative and psychotherapy: Practice, theory and research. London 2004.

Rivett, M., Buchmüller, J. \& Oliver (2018). Family therapy skills and techniques in action. London 2018.

Sayar, K. (2013). Terapi: Kültürel bir eleş̧tiri (4. Baskı). İstanbul 2013.

Semmler, P. L., \& Williams, C. B. (2000). "Narrative therapy: A storied context for multicultural counseling". Journal of Multicultural Counseling and Development 28/1 (2000) 51-62.

Shapiro, J., \& Ross, V. (2002). "Applications of narrative theory and therapy to the practice of family medicine". Family Medicine 34/2 (2002) 96-100.

Tarragona, M. (2008). "Postmodern/Poststructuralist Therapy". 21st Century Psychotherapies (2008) 167-205.

Vromans, L. P., \& Schweitzer, R. D. (2011). "Narrative therapy for adults with major depressive disorder: Improved symptom and interpersonal outcomes". Psychotherapy research 21/1 (2011) 4-15.

White, M. (2000). "Reflections on narrative practice: Essays and interviews". Adelaide 2000.

White, M. K. (1995). Re-authoring lives: Interviews \& essays. Adelaide 1995.

White, M., \& Epston, D. (1990). Narrative Means to Therapeutic Ends. New York 1990.

White, M., Epston, D. (2005). Externalizing The Problem. Relating Experience: Stories from Health and Social Care. New York 2005.

Yazıcı, B. (2018). Naratif Terapi Temelli Grupla Psikolojik Danışma Programının Ergenlerin Psikolojik Dayanıklllık Düzeylerine Etkisi. Yayımlanmamış Yüksek Lisans tezi. Maltepe Üniversitesi, İstanbul. 